\title{
The Discovery of Macitentan - A Standard Medicinal Chemistry Program?
}

\author{
Martin H. Bolli* \\ KGF-SCS Industrial Investigator Award 2016
}

\begin{abstract}
A plethora of properties are typically studied during a medicinal chemistry program and many of these parameters may shape the cascade of compound selection. Given the task to discover a molecule with a profile superior to that of the dual endothelin receptor antagonist bosentan, we tailored our compound profiling cascade to the specific properties that were not optimal in bosentan, namely in vivo efficacy and safety. Contrary to conventional thinking, we therefore focused on corresponding in vivo experiments. In the following, we highlight and illustrate some key learnings of our approach that led to the discovery of macitentan (1), an orally available potent dual endothelin receptor antagonist approved for the treatment of pulmonary arterial hypertension.
\end{abstract}

Keywords: Endothelin receptor antagonist $\cdot$ Macitentan $\cdot$ Medicinal chemistry $\cdot$ Pulmonary arterial hypertension

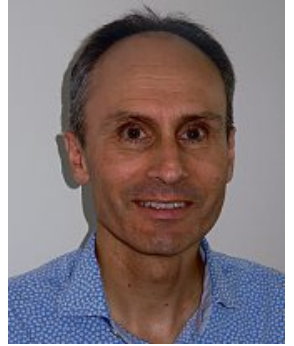

diseases. Dr. Bolli has published close to 100 scientific papers and patent applications.

\section{Historical Background}

In 1997 Actelion Pharmaceuticals Ltd. was founded by Jean-Paul and Martine Clozel, Walter Fischli, and Thomas Widmann, four researchers who shared their passion for discovering and developing novel molecules interacting with the endothelin (ET) system. For about a decade, the four researchers and their teams had been working at the forefront of endothelin science at Roche. Their early studies described the ET system in physiology and pathology in great detail ${ }^{[1-5]}$ and suggested that molecules interacting with the ET receptors could potentially hold great promise for the treatment of a large number of cardiovascular diseases. ${ }^{[6-10]}$ Medicinal chemistry efforts at Roche soon led to the discovery of such molecules ${ }^{[11]}$ and studies with a first orally active small molecule inhibitor of the two ET recepmod, and cenerimod. Upon the acquisition of Actelion by Janssen Pharmaceutical, a company of Johnson\&Johnson, Dr. Bolli and his team joined the newly established company Idorsia Pharmaceuticals Ltd. where they aim at identifying novel drugs interfering with biological mechanisms associated with cardiovascular and fibrotic

*Correspondence: Dr. M. Bolli Idorsia Pharmaceuticals, Ltd. Hegenheimermattweg 91, CH-4123 Allschwil E-mail: martin.bolli@idorsia.com

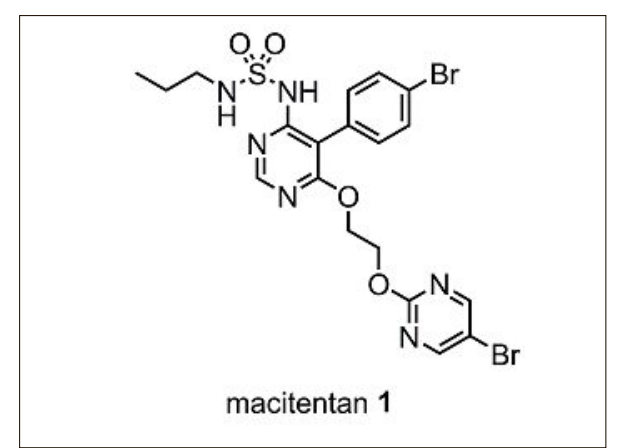

Fig. 1. Molecular structure of macitentan (1). tors underscored the pathological role of endothelin-1. ${ }^{[6]}$ In 1995 a Phase II clinical trial had already been performed in chronic heart failure patients with bosentan (2), a potent orally active inhibitor of both the $\mathrm{ET}_{\mathrm{A}}$ and the $\mathrm{ET}_{\mathrm{B}}$ receptor. ${ }^{[12-14]}$ While clinical development of bosentan was on-going in chronic heart failure (CHF), the four researchers decided to create their own company named Actelion with the aim to extend bosentan's clinical development to other indications. When Roche discontinued clinical development of bosentan in $\mathrm{CHF}^{[15]}$ in 1998, Actelion was able to in-license bosentan and to follow its own clinical development plans. At the same time, it was the founders' clear vision to establish a research organisation within the newly formed company that embarked on the search for innovative drugs. Hence, shortly after its foundation Actelion hired a number of biologists, pharmacologists, and chemists with the mandate to fuel Actelion's research and development pipeline. This was the time when I joined Actelion - a very young company that just moved into empty lab and office space. One of our first tasks was to identify a novel endothelin receptor antagonist (ERA) with improved properties when compared to bosentan.

\section{The Endothelin System}

In 1988, Yanagisawa et al. ${ }^{[16]}$ characterized a 21-amino acid peptide, endothelin-1 (ET-1) that they had isolated from the supernatant of porcine aortic endothelial cells as one of the most potent vasoconstrictors. At the same time, the Roche team had already demonstrated that this novel 
vasoconstrictor is also produced by human endothelial cells and binds to a specific binding site on human vasculature smooth muscle cells..$^{[1,3]}$ Later it was found that this peptide is in fact a member of a family of three closely related peptides, ET-1, ET2, and ET-3, that convey their biological activity through binding to two G-protein coupled receptors named $\mathrm{ET}_{\mathrm{A}}$ and $\mathrm{ET}_{\mathrm{B}}$. While ET-1 and ET-2 bind and activate the $\mathrm{ET}_{\mathrm{A}}$ receptor with high affinity, all three peptide homologs are potent agonists of the $\mathrm{ET}_{\mathrm{B}}$ receptor. In addition to their vasoactivity, endothelins are upregulated in pathology and promote cell proliferation, inflammation, tissue remodelling and fibrosis. ${ }^{[17,18]}$ Based on their mechanism of action, ERAs were proposed to be useful in a number of cardiovascular (e.g. hypertension, pulmonary hypertension, atherosclerosis, congestive heart failure, myocardial infarction), renal (e.g. chronic kidney failure), fibrotic (e.g. pulmonary fibrosis) and proliferative diseases (e.g. prostate cancer, ovarian cancer, melanoma).[9,17,19-22]

Under physiological conditions, blood vessels react in a bi-phasic fashion to the stimulation by exogenous ET-1 (Fig. 2). A transient vasodilation mediated by the activation of $\mathrm{ET}_{\mathrm{B}}$ receptors on endothelial cells characterizes a first response. In a second phase, $\mathrm{ET}_{\mathrm{A}}$ receptors that are predominantly expressed on vascular smooth muscle cells provoke a strong and sustained vasoconstriction. In animal models of cardiovascular diseases, however, not only ET-1 levels but also $\mathrm{ET}_{\mathrm{B}}$ receptors are up-regulated in vascular tissue and no longer mediate vasodilation but rather enhanced vasoconstriction. ${ }^{[7,10,23-25]}$ Dual $\mathrm{ET}_{\mathrm{A}}$ and $\mathrm{ET}_{\mathrm{B}}$ receptor antagonism therefore appeared superior to us in terms of efficacy as compared to selective $\mathrm{ET}_{\mathrm{A}}$-receptor blockade. ${ }^{[26-28]}$ In addition, we believed dual ERAs provided a better safety profile as increased chronic $\mathrm{ET}_{\mathrm{B}}$ receptor activation in the presence of $\mathrm{ET}_{\mathrm{A}}^{\mathrm{B}}$ selective blockade was associated with undesired cell proliferation and fluid retention. ${ }^{229,30]}$ The benefits of dual ET receptor blockade were further substantiated by pre-clinical as well as clinical studies. ${ }^{[25,26,28,31-34]}$

\section{Bosentan's Properties}

Bosentan was characterised as a potent dual ERA showing efficacy in animal models of several cardiovascular diseases (reviewed in ref. [35]) such as chronic heart failure ${ }^{[26,36,37]}$ and pulmonary hypertension. ${ }^{[38,39]}$ In in vitro binding assays using membranes of recombinant $\mathrm{CHO}$ cells overexpressing the corresponding ET receptor, bosentan showed $\mathrm{K}_{\mathrm{i}}$ values of 6.5 and 343 $\mathrm{nM}$ on the $\mathrm{ET}_{\mathrm{A}}$ and $\mathrm{ET}_{\mathrm{B}}$ receptor, respectively. In functional tests with isolated rat

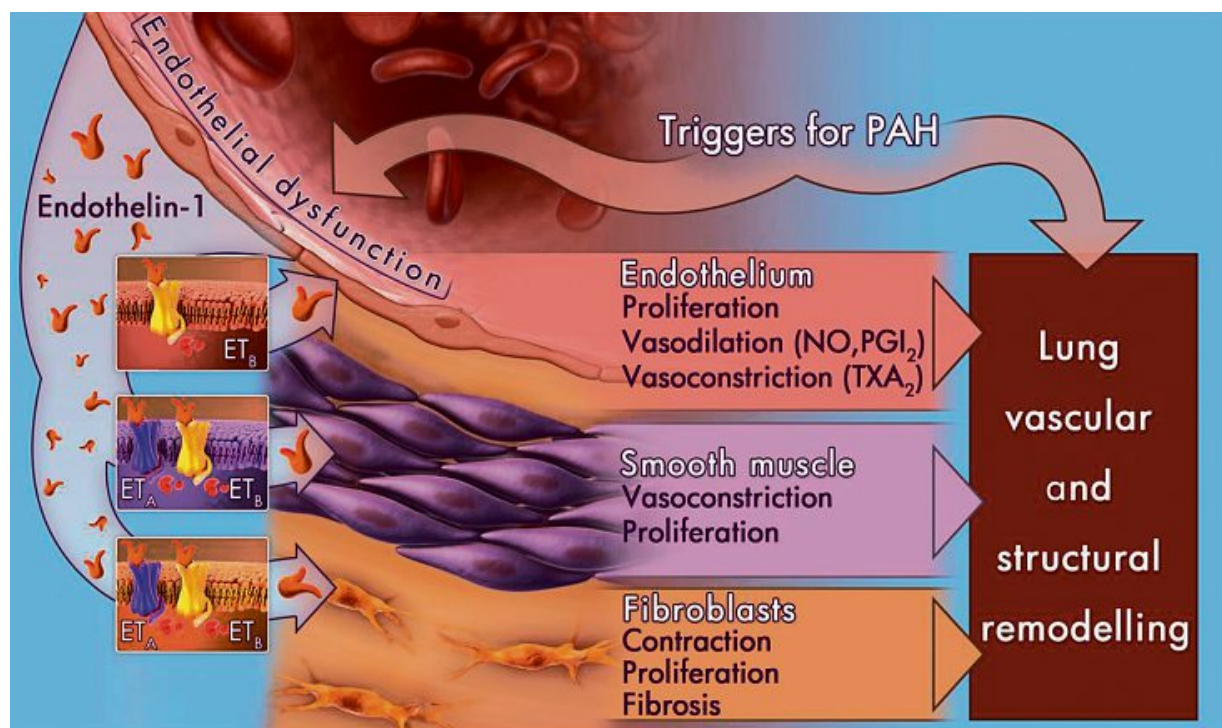

Fig. 2. Illustration of the effects of the endothelin system on the lung in pulmonary arterial hypertension. Endothelial cells produce endothelin-1 that can act in an autocrine and paracrine fashion. By activating $\mathrm{ET}_{\mathrm{B}}$ receptors on endothelial cells, $\mathrm{ET}-1$ induces cell proliferation, and vasodilation or vasoconstriction. On smooth muscle cells, stimulation of $\mathrm{ET}_{\mathrm{A}}$ and $E \mathrm{~T}_{\mathrm{B}}$ by $\mathrm{ET}-1$ leads to vasoconstriction and proliferation. Fibroblasts also express both ET receptors and contract and proliferate upon stimulation with ET-1. Adapted from Dupuis et al. ${ }^{[23]}$

aorta and trachea rings, bosentan acted as a potent and competitive antagonist of ET-1 (aorta, $\mathrm{ET}_{\mathrm{A}}$ ) and sarafotoxin S6c (trachea, $\mathrm{ET}_{\mathrm{B}}$ ). Bosentan was able to reduce blood pressure in several rat models of hypertension. ${ }^{[35]}$ In pithed rats, bosentan reduced the blood pressure increase induced by i.v. injection of big-ET-1 in a dose-dependent fashion. ${ }^{[12]}$ Long-term treatment with bosentan of rats with chronic heart failure significantly decreased post-charge as measured by mean arterial pressure (MAP) and increased survival.[37] Furthermore, bosentan attenuated the monocrotaline induced increase in mean pulmonary arterial pressure (MPAP) in this rat model of pulmonary hypertension. ${ }^{[40]}$ By 1998, phase II clinical trials with bosentan in chronic heart failure $(\mathrm{CHF})^{[13,14,41]}$ and essential hypertension $^{[42]}$ had been completed while phase III trials in pulmonary arterial hypertension $(\mathrm{PAH})$ patients $^{[43-45]}$ were in preparation. In these trials increases in aminotransferase (ALT and AST) levels of more than three times the upper limit of normal (ULN) were observed in $10-15 \%$ of patients receiving bosentan and a dose of $125 \mathrm{mg}$ b.i.d was identified as optimal balance of efficacy and safety. ${ }^{[46-48]}$

\section{Project Goal \& Screening Cascade}

With this background we set out to identify a novel ERA optimized for chronic use, ideally being more efficacious, longer lasting and devoid of liver liability. In theory and reflecting in hindsight, we considered that this might be achieved by at least two alternative approaches. On one hand we could have aimed at improving the potency of the compound such that the exposures needed to achieve efficacy in vivo would be below the threshold that triggers liver toxicity. In such an approach, the profiling cascade for selecting compounds would focus on assays that characterise the compound's in vitro potency and in vivo efficacy. On the other hand, one could try to remove the liver liability per se. For this approach to be successful a relevant in vitro or in vivo assay that allows characterisation of the compounds with respect to their potential liver toxicity was required. Fattinger et al. developed an assay based on the observation that the clinical increases in liver transaminase are likely the consequence of inhibition of the canalicular bile salt export pump (BSEP) and the subsequent intrahepatic accumulation of bile salts by bosentan. ${ }^{[49]}$ In vitro, bosentan inhibited taurocholate transport in vesicles overexpressing the rat or human export pump. In the rat, increased serum bile salt levels observed after i.v. injection of bosentan mimicked the cholestatic effect observed in patients with liver injury. We therefore decided to include plasma bile salt measurements after i.v. injection of our compounds to rats as a key characterisation step in our profiling cascade. By combining the two approaches mentioned above, our profiling cascade was based on the following cornerstones (Fig. 3): potency on the $\mathrm{ET}_{\mathrm{A}}$ and $\mathrm{ET}_{\mathrm{B}}$ receptor was first assessed by a ${ }^{125}$ I-ET- 1 competitive binding assay using membranes of $\mathrm{CHO}$ cells overexpressing either of the two receptors. In a second step, the functional potency of our compounds was assessed by measuring 
their ability to inhibit the ET-1 and sarafotoxin S6c induced constriction of isolated rat aorta and trachea rings, respectively (Fig. 4). Efficacy of compounds that were at least as potent as bosentan in these prior assays was then assessed by measuring their ability to reduce blood pressure in hypertensive Dahl salt-sensitive rats equipped with a telemetry system (Fig. 5). This model has been validated with bosentan and the set-up of the experiment allowed testing of 4 to 5 compounds per week. At the selected screening dose of $3 \mathrm{mg} / \mathrm{kg}$ only about $12 \mathrm{mg}$ of compound was required. Based on our experiences working in this area, we were able to rapidly test a relatively large number of compounds enabling us to study the in vivo structure activity relationship. In a second rat experiment, plasma ET-1 level increase after oral compound administration was measured as a means to assess efficient $\mathrm{ET}_{\mathrm{B}}$ receptor blockade in vivo. ${ }^{[50,51]}$ Finally, as mentioned above, absence of interference with hepatic bile salt transport was assessed by measuring plasma bile salt changes after i.v. administration of $25 \mathrm{mg} / \mathrm{kg}$ of the compound to rats. While our profiling cascade outlined in Fig. 3 was complemented with additional in vitro data e.g. on cytochrome $\mathrm{P} 450$ inhibition, hERG channel blockade, etc., compound advancement heavily relied on in vivo rather than in vitro data. Indeed, our approach is in strong contrast to what is considered a standard medicinal chemistry approach in which many more properties would be assessed using in vitro and in silico methods (Fig. 6) to prioritize the compounds.

In the above assays, bosentan showed $\mathrm{IC}_{50}$ values of 45 and $202 \mathrm{nM}$ on the ET and $\mathrm{ET}_{\mathrm{B}}$ receptors, and $\mathrm{pA}_{2}$ values of 6.78 and 6.47 in contraction experiments with isolated rat aorta and trachea, respectively. In hypertensive Dahl salt-sensitive rats, bosentan decreased blood pressure with an area between vehicle and treatment curve (ABC) of $-88 \mathrm{mmHg} \times \mathrm{h}$ at an oral dose of $3 \mathrm{mg} / \mathrm{kg}$ (Fig. 5B). ${ }^{[52]}$ Ten minutes after intravenous injection of $25 \mathrm{mg} / \mathrm{kg}$ to Wistar rats, bosentan induced an $18 \mu \mathrm{M}$ increase in plasma bile salts. ${ }^{[53]}$ In order for our novel ERA to be superior to bosentan, we set the following thresholds for compound advancement in our profiling cascade: $\mathrm{IC}_{50}$ values of $<20$ and $<400 \mathrm{nM}$ on the $\mathrm{ET}_{\mathrm{A}}$ and $\mathrm{ET}_{\mathrm{B}}$ receptor, respectively; $\mathrm{pA}_{2}$ values of $>7$ and $>6$ in the isolated rat aorta and trachea constriction experiment, respectively; an $\mathrm{ABC}$ of $<-500 \mathrm{mmHg} \times \mathrm{h}$ as calculated from the blood pressure recordings in Dahl rats; and no effect on plasma bile salt levels upon i.v. administration of $25 \mathrm{mg} / \mathrm{kg}$ of the compound to rats. These thresholds were set based on our own internal knowledge and creativity in attempting to discover a novel ERA.

\section{Starting Points}

It is interesting to note what Werner Neidhart, one of the inventors of bosentan, wrote about the challenge of finding small molecule ERAs in 1988: “... the general opinion then was that it would constitute a major challenge to substitute a large peptide hormone by a small molecule binder to compete for a G-protein coupled receptor..."[56] When we embarked on our program ten years later, our analysis of the competitive landscape of the ERA field revealed more than 150 patent applications disclosing small molecule ERAs and about a dozen compounds, mostly selective for the $\mathrm{ET}_{\mathrm{A}}$ receptor, had already entered clinical trials for several indications (Fig. 7). ${ }^{[20,57-61]}$ In view of this large number of structures known to interact with the endothelin receptors, we decided to select our starting points for a medicinal chemistry program from already known ERAs rather than to perform a high-throughput screen-

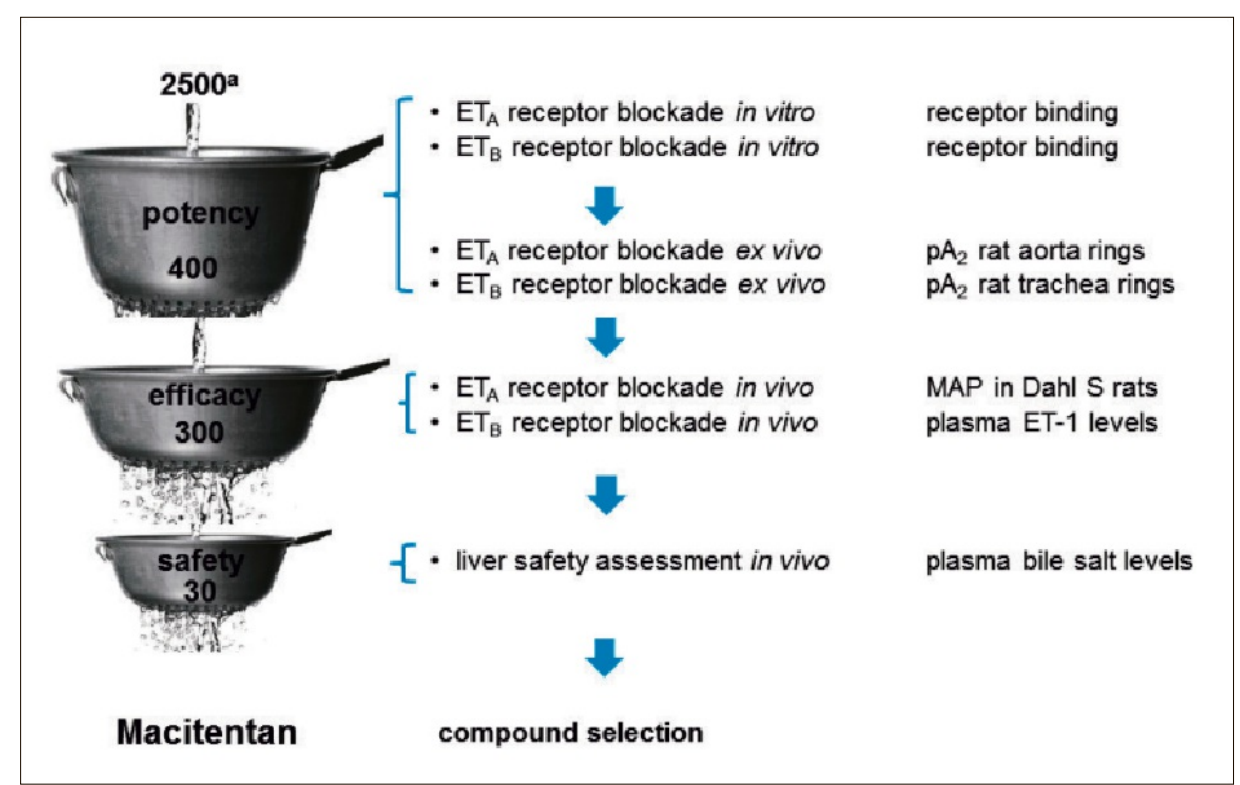

Fig. 3. The compound profiling cascade; afigures indicate number of compounds prepared and tested in the corresponding assays; MAP = mean arterial pressure.

A

\begin{tabular}{lcc}
\hline Tissue & Receptor & Agonist \\
\hline Aorta ring & $\mathrm{ET}_{\mathrm{A}}$ & $\mathrm{ET}-1$ \\
Trachea ring & $\mathrm{ET}_{\mathrm{B}}$ & Sarafotoxin S6c \\
\hline
\end{tabular}

B
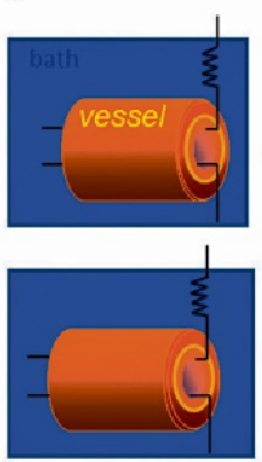

\section{agonist} contraction

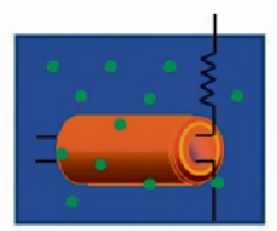

1 compound

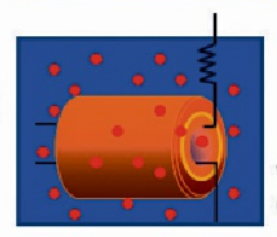

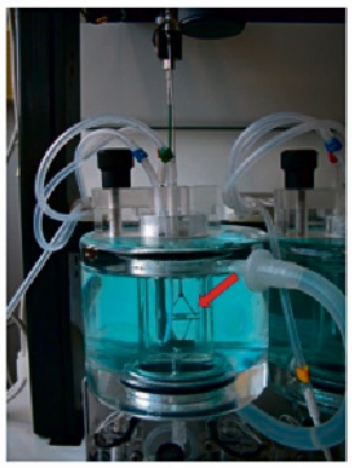

agonist

$\overrightarrow{\text { weak or no }}$ contraction

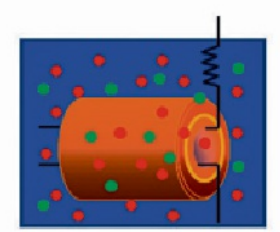

Fig. 4. Ex vivo functional potency assessment. A) ET receptor predominantly expressed in rat aorta and trachea rings and the corresponding agonist used. B) Rat aorta or trachea rings constrict upon stimulation with the endothelin receptor agonists ET-1 and sarafotoxin S6c, respectively. Pre-incubation of the tissue with an ERA attenuates/abolishes the constriction induced by the agonist. $\mathrm{pA}_{2}$ values were calculated by Schild plot analyses of the dose-response curves; for example, at a concentration of $1 \mathrm{nM}\left(10^{-9} \mathrm{M}\right)$ a compound with a $\mathrm{pA}_{2}$ value of 9 is able to shift the $\mathrm{EC}_{50}$-value of the agonist by a factor 2; C) Organ bath with mounted tissue preparation (red arrow). For details see ref. [54]. 


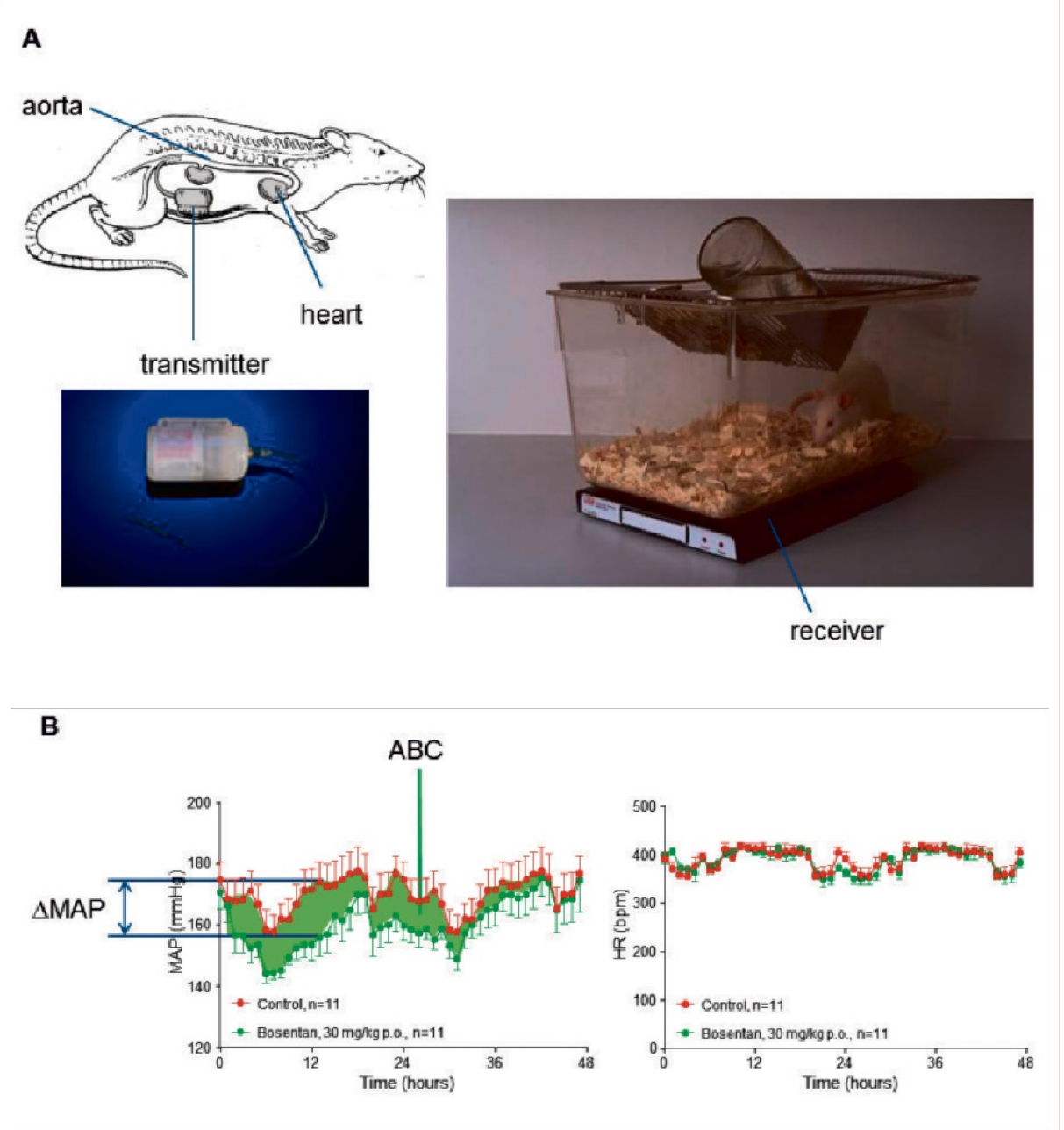

Fig. 5. A) Schematic view and picture of a rat equipped with a telemetry system measuring mean arterial blood pressure (MAP) and heart rate (HR). Adapted from Data Sciences International, St. Paul, MN, USA and refs $[40,55]$. B) Example of MAP (left) and HR (right) recordings in telemetrized hypertensive Dahl salt-sensitive rats showing maximal $\triangle \mathrm{MAP}(-14 \pm 7 \mathrm{mmHg})$ and $\mathrm{ABC}$ $(-343 \mathrm{mmHg} \times \mathrm{h})$ as calculated between the MAP curves before (control) and after administration of $30 \mathrm{mg} / \mathrm{kg}$ of bosentan. At a dose of $3 \mathrm{mg} / \mathrm{kg}$ the $A B C$ was $-88 \mathrm{mmHg} \times \mathrm{h}$ (graph not shown). The HR is measured as a control to confirm that there is no HR increase as a response to the MAP reduction.

\begin{tabular}{|c|c|c|}
\hline $\begin{array}{l}\text { Design Parameters } \\
\text { - molecular weight } \\
\text { - clogP } \\
\text { - \# H donors/acceptors } \\
\text { - PSA } \\
\text { Ligand Efficiency Metrics } \\
\text { - ligand efficiency (LE) } \\
\text { - ligand lipophilicity efficiency ( }\end{array}$ & $\begin{array}{l}\text { Physicochemistry } \\
\text { : } \log \mathrm{P} \\
\text { : } \log \mathrm{D} \\
\text { - pKa } \\
\text { : } \text { solubility } \\
\text { - permeability }\end{array}$ & 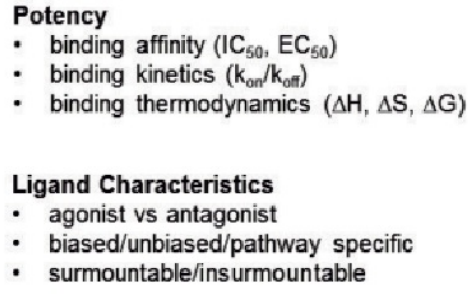 \\
\hline $\begin{array}{ll}\text { Metabolic stability } \\
\text { - } & \mathrm{CL}_{\text {int }} \text { liver microsomes } \\
\text { - } & \mathrm{CL} \text { int hepatocytes } \\
\text { plasma stability }\end{array}$ & $\begin{array}{l}\text { Transporter Affinities } \\
: \quad \text { MDR1/P-gp } \\
\text { - OATP } \\
\text { * } \text { BSEP }\end{array}$ & $\begin{array}{ll}\text { Safety } \\
\text { * } & \text { CYP inhibition } \\
\text { - } & \text { hERG blockade } \\
\text { * } & \text { glutathion trapping } \\
\text { - } & \text { broad off-target screen }\end{array}$ \\
\hline $\begin{array}{l}\text { PK/PD Correlation/Prediction } \\
\text { - plasma protein binding } \\
\text { - tissue binding }\end{array}$ & $\begin{array}{l}\text { Pharmacokinetics } \\
\text { - } \quad \text { exposure }\left(\mathrm{C}_{\max }, \mathrm{AUC}\right) \\
\text { - clearance }(\mathrm{Cl}) \\
\text { - } \text { half-life }\left(\mathrm{t}_{1 / 2}\right) \\
\text { - } \\
\\
\quad \text { tissue distribution } \\
\left.\text { (e.g. } \mathrm{V}_{\mathrm{ss}}\right)\end{array}$ & $\begin{array}{l}\text { In Vivo Efficacy } \\
\text { - } \quad \text { target engagement } \\
\text { - biomarker } \\
\text { - } \text { animal disease model }\end{array}$ \\
\hline
\end{tabular}

Fig. 6. Parameters that often form part of a screening cascade in a standard medicinal chemistry program; blue = calculated properties, black = properties measured in vitro, green = properties assessed in vivo. ing. We based our selection of a small set of starting points on the compounds' structural diversity as well as their ability to block both the $\mathrm{ET}_{\mathrm{A}}$ and the $\mathrm{ET}_{\mathrm{B}}$ receptor. This ultimately led us to consider the five compounds shown in Fig. 8.

\section{Project Progress}

Preparing and testing analogues of the five starting points separated the wheat from the chaff (Fig. 9). [62] The synthesis of IRL-3630 (14) ${ }^{[63]}$ analogues turned out to be more challenging than expected and as most of the prepared analogues were inactive this series was dropped early on. On the other hand, relatively easy synthetic access allowed to prepare a considerable number of analogues of pyrazole 16. ${ }^{[64}$ However, none of these variations led to a promising affinity for the ET receptors. Similarly, analogues of Banyu/Merck's L-754142 (15) ${ }^{[65]}$ did not live up to the initial expectations and the search for not yet patented structures retaining activity on the ET receptors was abandoned after a series of inactive molecules.

Hence, while we abandoned the three series that started from IRL-3630 (14), L-754142 (15) and the Roussel compound 16 relatively early, investigations in the series inspired by ambrisentan ${ }^{[66]}$ and bosentan continued head to head. Already first novel derivatives of ambrisentan and bosentan showed interesting biological activities. On the one hand, rigidifying the structure of ambrisentan by introducing a ring between the methoxy group and one of the phenyl rings led to novel molecules that could be optimized readily for their affinity for the two ET receptors. In particular benzo[1,4]diazepin-2-one such as compound 17 (Fig. 10A) represented highly potent dual ERAs.

The series of pyrimidine derivatives that evolved from bosentan turned out to be the workhorse of our drug discovery program. As we explored the SAR of this series, we came across several surprises. Pyrimidine-based ERAs previously disclosed by Roche, Tanabe, Shionogi, Yamanouchi, and Kowa invariably contained a rather large substituent at the sulfonamide moiety suggesting that a bulky substituent is needed for high affinity. ${ }^{[60,67]}$ However, as shown by the compounds in Table 1, even much smaller substituents (e.g. compounds $\mathbf{2 0 , 2 1}$ ) in this part of the molecule led to potent ERAs. ${ }^{[52]}$ In addition, replacing the alkyl chain in the sulfonamide by an alkylamino group to yield a sulfamide improved the compound's affinity for the two ET receptors, in particular $\mathrm{ET}_{\mathrm{B}}$ (compare 22 with $\mathbf{2 0}$, and compounds in Table 2). In fact, the affinity for the $\mathrm{ET}_{\mathrm{B}}$ receptor increased with increasing chain 


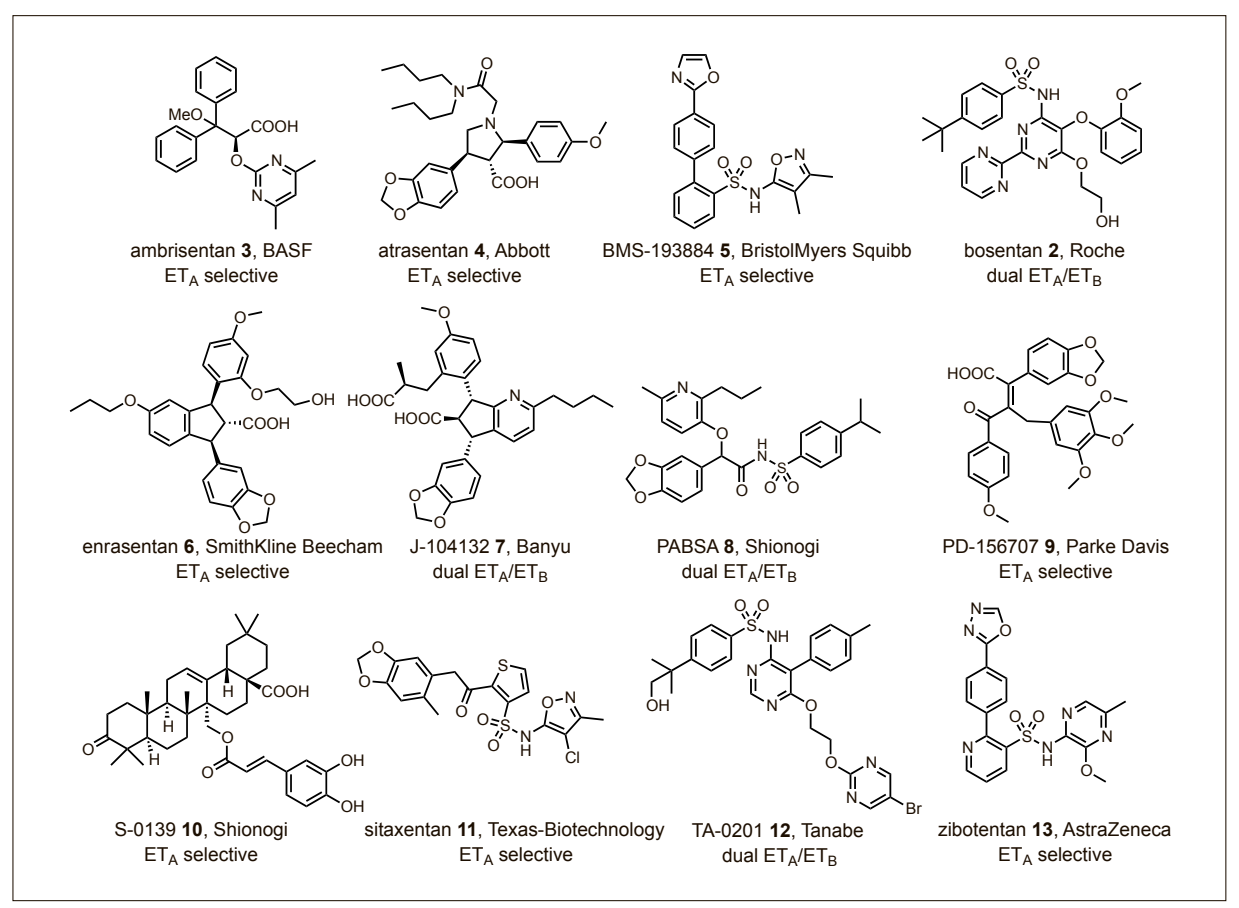

Fig. 7. Structures of some ERAs that entered clinical development up to 2001.<smiles>COc1ccccc1Oc1c(NS(=O)(=O)c2ccc(C(C)(C)C)cc2)nc(-c2ncccn2)nc1OCCO</smiles>

bosentan 2 $\mathrm{IC}_{50} \mathrm{ET}_{\mathrm{A}} 80 \mathrm{nM}$ $\mathrm{ET}_{\mathrm{B}} 150 \mathrm{nM}$
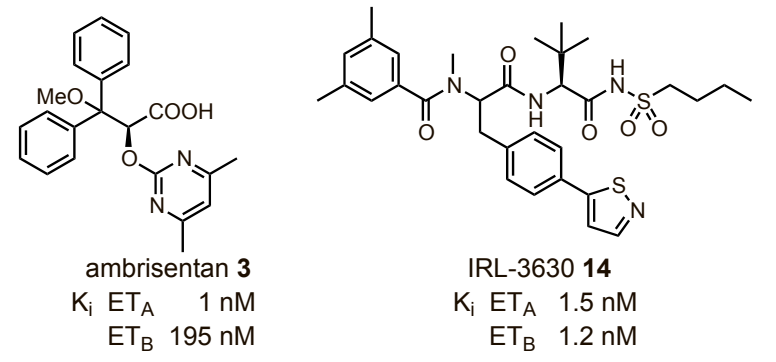

IRL-3630 14

$\mathrm{K}_{\mathrm{i}} \mathrm{ET}_{\mathrm{A}} 1.5 \mathrm{nM}$

$\mathrm{ET}_{\mathrm{B}} 1.2 \mathrm{nM}$

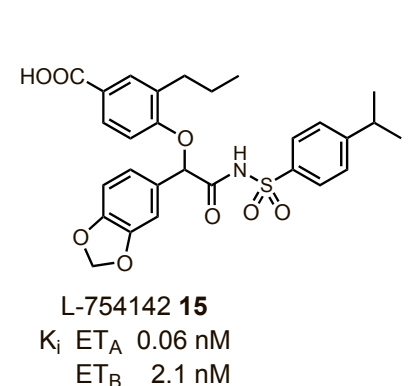

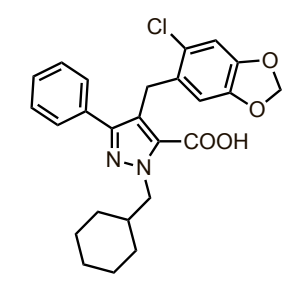

Roussel 16

$\mathrm{IC}_{50} \mathrm{ET}_{\mathrm{A}} 3.6 \mathrm{nM}$

$\mathrm{ET}_{\mathrm{B}} 2.6 \mathrm{nM}$

Fig. 8. The structures of the five starting points selected for our medicinal chemistry program.

Fig. 9. Evolution of the $\mathrm{ET}_{\mathrm{A}}$ affinity of the five compound series starting from: bosentan (2, blue), ambrisentan (3, red), IRL-3630 (14, yellow), L-754142 (15, green), and the Roussel compound (16, orange); macitentan $(\mathbf{1}$, circled in dark blue).

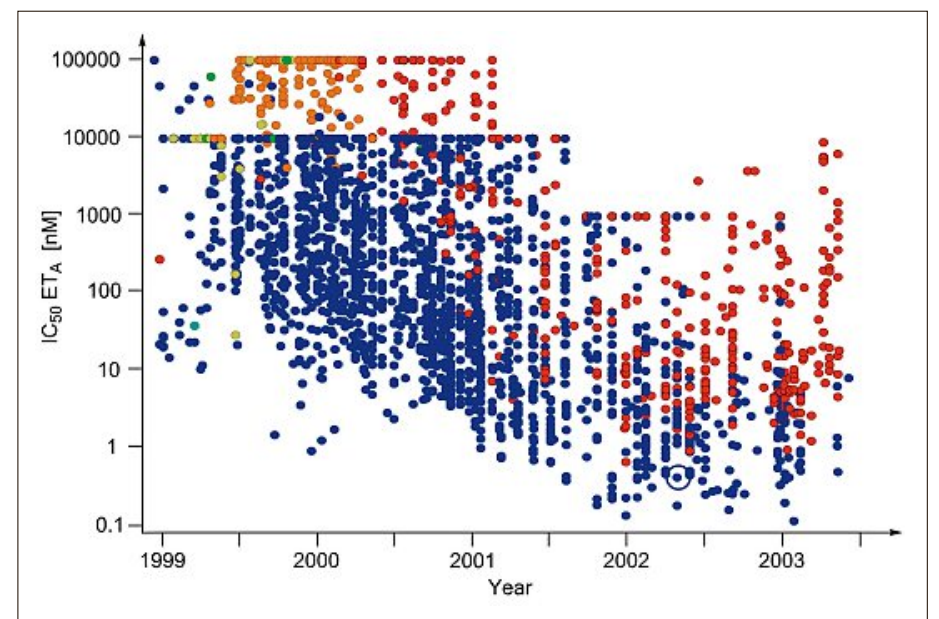

length of the alkyl sulfamide moiety $(\mathbf{1}, 27$ to 29). These findings were not obvious or even remotely suggested in the literature. As most if not all previously described ERA contained an acidic functional group such as a carboxylic acid, an acyl or heteroaryl sulfonamide[60,67] we speculated that this acid plays an important role in the interaction with the receptor. One could therefore contemplate that the less acidic sulfamide ( $\mathrm{pK}_{\mathrm{a}} \sim 6$ ) may lose affinity for the ET receptor when compared to the more acidic sulfonamide $\left.\left(\mathrm{pK}_{\mathrm{a}} \sim 5\right)\right)^{[54]}$ However, as illustrated by the examples in Table 1, this is not the case. More recent binding studies with receptor mutants confirmed that in contrast to the sulfonamides (e.g. bosentan) and carboxylic acids (ambrisentan), the sulfamides' affinity for the $\mathrm{ET}_{\mathrm{A}}$ receptor does not depend on strong charge-charge interactions. ${ }^{[68]}$

As we obtained a growing number of novel pyrimidine and benzodiazepinone derivatives with high affinity for the ET receptors, we started to explore the functional potency of compounds that showed $\mathrm{IC}_{50}$ values below $20 \mathrm{nM}$ and $400 \mathrm{nM}$ on $\mathrm{ET}_{\mathrm{A}}$ and $\mathrm{ET}_{\mathrm{B}}$ in the binding assay, respectively. For both the pyrimidine as well as the benzodiazepinone series, the $\mathrm{pA}_{2}$ values obtained in the isolated rat aorta and trachea constriction experiment correlated with the $\mathrm{IC}_{50}$ values of the $\mathrm{ET}_{\mathrm{A}}$ and $\mathrm{ET}_{\mathrm{B}}$ receptor binding, respectively, - albeit with significant scattering (Fig. 11; for $\mathrm{IC}_{50} \mathrm{ET}_{\mathrm{B}} \mathrm{vs} \mathrm{pA}_{2}$ trachea see ref. [62]). These observations confirmed that the compound's ability to block agonist-induced vessel constriction not only depends on its affinity for the ET receptor but is also influenced by other factors. We speculated that compound lipophilicity, ability to penetrate tissue, unspecific tissue binding and receptor binding kinetics may be among these contributing factors but we were not able to unambiguously confirm these hypotheses. Nevertheless, the $\mathrm{pA}_{2}$ values were a useful tool to further shortlist the most interesting compounds and we decided that compounds with a functional potency greater than the one of bosentan $\left(\mathrm{pA}_{2}\right.$ aorta $>6.8$ ) shall be characterized in the in vivo hypertension model.

The efficacy to reduce the mean arterial blood pressure of hypertensive Dahl salt-sensitive rats was assessed for about 70 benzodiazepinones and almost 300 pyrimidines. In vivo efficacy was assessed by calculating the area between the mean arterial pressure (MAP) recordings before and after oral compound administration. First experiments revealed that for the benzodiazepinones to show activity in vivo a dose of $30 \mathrm{mg} / \mathrm{kg}$ was needed, while for the pyrimidines $3 \mathrm{mg} / \mathrm{kg}$ was sufficient to obtain a significant pharmacological response. This 10-fold difference in required dose persisted throughout our discovery pro- 
gram and clearly separated the pyrimidines from the benzodiazepinones (Fig. 12). Nevertheless, several representatives of the benzo[1,4]diazepin-2-one-derived ERAs showed efficacy in the hypertensive Dahl salt-sensitive rats that was superior to that of ambrisentan and bosentan at equal dose (e.g. Fig. 10). ${ }^{[52,69]}$ Plotting the in vivo efficacy data (MAP ABC) of the pyrimidine and benzodiazepinone derivatives against the aorta $\mathrm{pA}_{2}$ values revealed a clear trend for compounds with higher $\mathrm{pA}_{2}$ to also show oral activity. Compounds reaching an $\mathrm{ABC}$ of $>1000 \mathrm{mmHg} \times$ h typically had a $\mathrm{pA}_{2}$ value of $>7.5$ on rat aorta rings, suggesting that a high $\mathrm{pA}_{2}$ is necessary but not sufficient for a compound to show in vivo efficacy. This observation is not surprising as in vivo efficacy is of course not only driven by the compound's potency but also by its pharmacokinetic behaviour. However, rather than analysing the pharmacokinetic behaviour of our compounds in more detail, we tried to identify the structure-activity relationship driving in vivo efficacy. In the following, a few key observations are summarized. For instance, the nature of the substituent attached to the 5-position of the core pyrimidine significantly impacted the efficacy in vivo. The efficacy of the corresponding compounds often followed the order 2-methoxyphenoxy $<3$-methoxyphenoxy $<3$-methoxy-6-chlorophenoxy, 4-chlorophenyl, 4-bromophenyl (Table 3). In several series, the 4-bromophenyl moiety clearly delivered the most efficacious example (e.g. 30 to $\mathbf{3 4}$, Table 4). ${ }^{[52]}$ Another important observation is illustrated with the examples compiled in Table 2. In the sulfonamide (23 to $\mathbf{2 6}$ ) as well as in the sulfamide $(\mathbf{1}, \mathbf{2 7}$ to $\mathbf{2 9})$ series, the in vivo efficacy appeared to decrease with increasing chain length of the alkyl sulfonamide and sulfamide moiety. Together with the observation that the compounds' affinity for the $\mathrm{ET}_{\mathrm{B}}$ receptor increased with increasing chain length (see 1, 27 to 29), the propyl chain represented the best compromise between high potency on $\mathrm{ET}_{\mathrm{B}}$ and high efficacy in vivo. A last in vivo SAR element is illustrated with the nearly equipotent compounds listed in Table 5 incorporating different substituents in the 5-position of the lower pyrimidine. While the cyclopropyl (37) or a methoxy (38) derivative showed low in vivo efficacy at the tested dose, a methylthio (39) group or a bromine (34) atom yielded highly efficacious ERAs. For a handful of compounds, their ability to block the $\mathrm{ET}_{\mathrm{B}}$ receptor in vivo was assessed by measuring plasma ET-1 levels after oral administration of the compound to Wistar rats (data not shown). These internal data provided a further selection criterion. Overall, our efforts to have a relatively easy access to reliable, relevant and translatable in vivo efficacy
A

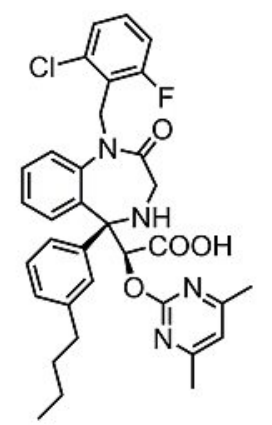

Benzo[1,4]diazepin-2-one 17

$\mathrm{IC}_{50} \mathrm{ET}_{\mathrm{A}} 7.6 \mathrm{nM} \quad \mathrm{pA}_{2}$ aorta 8.72

$\mathrm{ET}_{\mathrm{B}} 7.1 \mathrm{nM} \quad$ trachea 7.88

Dahl S ABC $-409 \mathrm{mmHg} \times \mathrm{h}$

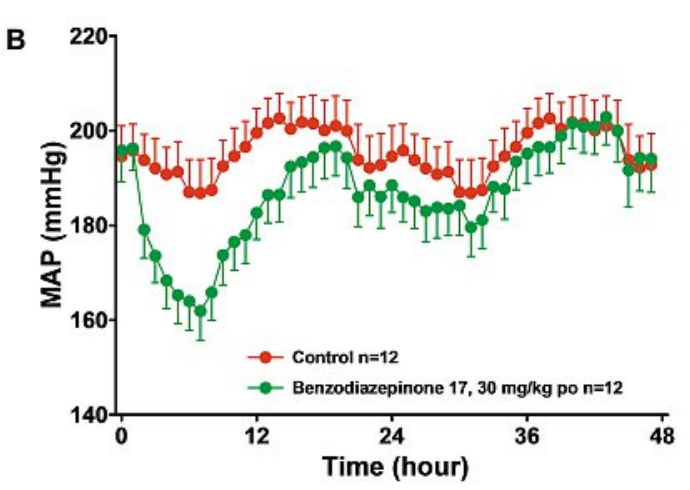

Fig. 10. A) Structure, in vitro and in vivo data of a highly potent and efficacious dual ERA derived from ambrisentan. B) Mean arterial blood pressure recordings $48 \mathrm{~h}$ before (control) and after administration of $30 \mathrm{mg} / \mathrm{kg}$ of benzo[1,4]diazepin-2-one (17) to hypertensive Dahl salt-sensitive rats. At the same dose, bosentan reached an $\mathrm{ABC}$ of $-343 \mathrm{mmHg} \times \mathrm{h}$.

Table 1. Potent ERAs containing small substituents at the sulfonamide moiety.[52]

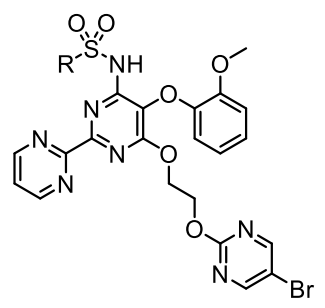

\begin{tabular}{cccc} 
Compound & $\mathrm{R}$ & \multicolumn{2}{c}{$\mathrm{IC}_{50}[\mathrm{nM}]$} \\
$\mathbf{1 8}$ & 4-tert-butyl phenyl & 1.5 & $\mathrm{ET}_{\mathrm{A}}$ \\
$\mathbf{1 9}$ & phenyl & 10.4 & 39.3 \\
$\mathbf{2 0}$ & ethyl & 14 & 460 \\
$\mathbf{2 1}$ & butyl & 4.3 & 552 \\
$\mathbf{2 2}$ & methyl-NH & 7.9 & 194
\end{tabular}

data facilitated the above SAR analyses that drove the discovery process.

Applying the criteria we set forth for compound advancement, about 30 compounds were found worthwhile to be tested in the plasma bile salt experiment. The results of these studies are shown in Fig. 13. None of the tested benzodiazepinones was inactive in this assay. However, while a few pyrimidine derivatives led to a plasma bile acid concentration increase similar to the one observed with bosentan, several representatives of this class caused no change in plasma bile salt levels. Unfortunately, the data set is too limited to derive a clear SAR. Mechanistic studies that were performed much later on the level of the hepatic transporters revealed that macitentan in fact inhibits BSEP with an $\mathrm{IC}_{50}$ value of $18 \mu \mathrm{M}$ and is thus at least as potent as bosentan for which $\mathrm{IC}_{50}$ val- ues of $25-77 \mu \mathrm{M}$ were reported. However, while bosentan is significantly transported by OATP, accumulates in hepatocytes and thus becomes hepatotoxic, macitentan distributes mainly by passive diffusion, does not accumulate in the liver and therefore does not lead to cholestasis. ${ }^{[53]}$

Taking the data generated so far together, macitentan (1) stood out as the best molecule of the 2500 molecules prepared combining optimized in vitro and ex vivo potency on the two ET receptors, with high efficacy in the Dahl hypertension model and the absence of interference with hepatic bile salt transport in vivo (Fig. 14). Based on these data and a series of experiments that supported that the favourable efficacy and safety profile of macitentan in the rat would translate to humans, macitentan was selected for further development. 
Table 2. In vitro potency and in vivo efficacy of sulfonamide and sulfamide derivatives. ${ }^{[52,67,82]}$<smiles>[R]OS(=O)(=O)Nc1ncnc(OCCOc2ncc(Br)cn2)c1-c1ccc(Br)cc1</smiles>

\begin{tabular}{clccc} 
Compound & & \multicolumn{2}{c}{$\mathrm{IC}_{50}[\mathrm{nM}]$} & $\mathrm{ABC}^{\mathrm{a}}$ \\
$\mathbf{2 3}$ & methyl & $\mathrm{ET}_{\mathrm{A}}$ & $\mathrm{ET}_{\mathrm{B}}$ & $\begin{array}{c}\text { R } \\
{[\mathrm{mmHg} \times \mathrm{h}]}\end{array}$ \\
$\mathbf{2 4}$ & ethyl & 1.9 & 1310 & -1639 \\
$\mathbf{2 5}$ & propyl & 2.2 & $>1500$ & -1911 \\
$\mathbf{2 6}$ & butyl & 2.2 & 3060 & -1116 \\
$\mathbf{2 7}$ & methyl-NH- & 1.1 & 2420 & -734 \\
$\mathbf{2 8}$ & ethyl-NH- & 1.7 & 812 & -1045 \\
$\mathbf{1}$ & propyl-NH- & 0.8 & 830 & -598 \\
$\mathbf{2 9}$ & butyl-NH- & 0.5 & 390 & -922 \\
& & 0.3 & 160 & -443
\end{tabular}

aat $3 \mathrm{mg} / \mathrm{kg}$ p.o.

Fig. 11. plC $_{50}$ values determined in the 125/-ET-1 competitive $E T_{A}$ binding assay versus $\mathrm{pA}_{2}$ values calculated from the isolated rat aorta constriction experiment; blue $=$ pyrimidine series, light blue $=$ bosentan; red = benzodiazepinone series.

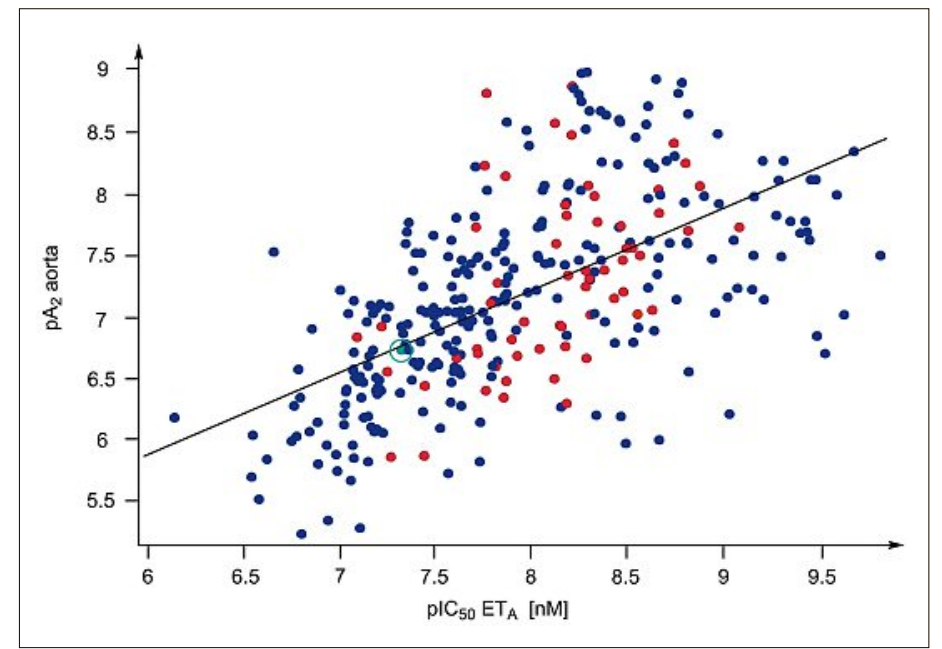

\section{Key Properties of Macitentan}

Several additional attractive properties clearly differentiated macitentan from bosentan. Macitentan showed a reduced acidity (pK 6.2 vs 5.1) and increased lipophilicity $\left(\log \mathrm{D}_{7.4} 2.9\right.$ vs 1.3$)$ when compared to bosentan. Detailed receptor binding studies revealed that macitentan has a significantly prolonged receptor occupancy half-life (17 min) when compared to bosentan (1 min). This increased receptor residence time was proposed to be the consequence of macitentan's increased lipophilicity and reduced acidity that made its interaction with the $\mathrm{ET}_{\mathrm{A}}$ receptor less dependent on charge-charge interactions. ${ }^{[68,70]}$ These altered physicochemical properties were also suggested to be responsible for macitentan's increased distribution into lung and right ventricle tissue in rats with bleomycin and monocrotalin induced pulmonary hypertension. ${ }^{[54,71]}$ To investigate whether these differences in receptor binding kinetics and tissue distribution were pharmacologically meaningful, macitentan was administered on top of a maximally efficacious dose of bosentan to hypertensive Dahl salt-sensitive rats. In these animals the mean arterial blood pressure (MAP) was further reduced by the additional administration of macitentan. Similarly, macitentan was also able to further reduce the mean pulmonary artery pressure (MPAP) when given on top of a fully efficacious dose of bosentan to rats with bleomycin-induced pulmonary hypertension. This greater maximal efficacy was considered to be the consequence of macitentan's more potent and sustained ET receptor inhibition. ${ }^{771,72]}$

Finally, in a pivotal long-term phase III clinical trial involving $742 \mathrm{PAH}$ patients (SERAPHIN trial), macitentan at a dose of $10 \mathrm{mg}$ q.d. significantly reduced the risk for the composite endpoint of morbidity/ mortality by $45 \%$. There was no sign for liver enzyme increases (ALT and AST) in patients receiving macitentan. ${ }^{[73]}$ These results formed the basis for macitentan's approval for the longterm treatment of PAH by health authorities around the globe.

\section{In vivo-based Compound Profiling Cascade - A Useful Concept?}

Realizing that integrating a rapid in vivo screening step into the compound profiling cascade expedited the advancement of our medicinal chemistry program, we envisaged applying this approach to other medicinal chemistry projects. Indeed, our sphingosine-1-phosphate receptor $1\left(\mathrm{~S}_{1} \mathrm{P}_{1}\right)$ agonist program offered such an opportunity. $S 1 P_{1}$ receptor agonists have been shown to sequester circulating lymphocytes to lymphoid organs and thus prevent autoreactive lymphocytes from doing harm to the tissue. ${ }^{[74-76]}$ The blood lymphocyte count (LC) can be measured rapidly and reliably and therefore serves as a valuable marker for in vivo activity of an $\mathrm{S}_{1} \mathrm{P}_{1}$ agonist. On this basis, we decided to include LC measurements as a key characterisation step in the compound profiling cascade. Similar to the endothelin project, the rapid availability and high reliability and relevance of LC data enabled us to build up the SAR linking structure, in vitro potency and in vivo activity that led to the discovery of ponesimod and cenerimod, two $S 1 \mathrm{P}_{1}$ receptor agonists in clinical development. Fig. 15 illustrates the different behaviour of two subclasses of potent $\mathrm{S} 1 \mathrm{P}_{1}$ receptor agonists in the $\mathrm{LC}$ experiment. While in one subclass a particular moiety was bound to a thiophene via an oxadiazole, in the second class the two fragments were connected via an ethyl ketone linker. At $3 \mathrm{~h}$ post dosing, both subclasses show a similar behaviour. Compounds with $\mathrm{EC}_{50}$ of $<20 \mathrm{nM}$ usually show maximal $\mathrm{LC}$ reduction ( $\mathrm{LC}<-60 \%$ ) confirming a rapid onset of action. At 24 $\mathrm{h}$, however, the two subclasses can clearly be differentiated. While the thiophene ketones lose activity (LC>-60\%), the oxadiazole derivatives still show sustained LC reduction ( $\mathrm{LC}<-70 \%)$. Some of the oxadiazoles even gained activity at $24 \mathrm{~h} .{ }^{[77,78]} \mathrm{A}$ similar analysis revealed clear differences between potent $\mathrm{S}_{1} \mathrm{P}_{1}$ agonists incorporating either a 2- or a 4-pyridine substituted 
oxadiazole. For both series compounds with an $\mathrm{EC}_{50}$ value $<20 \mathrm{nM}$ efficiently reduce the LC at $3 \mathrm{~h}$ post dosing. At $24 \mathrm{~h}$, the 2-pyridines clearly lose activity while most of the 4-pyridines retain full efficacy. ${ }^{[79-81]}$

\section{Conclusions}

We embarked on a medicinal chemistry program to identify a novel potent dual and orally active ERA starting from the structures of known ERAs and taking into account our knowledge acquired in prior years of research on the chemistry and pathophysiology of the ET system. To improve on our benchmark bosentan, we decided to set up a compound profiling cascade that emphasized on the use of reliable, relevant and translatable ex vivo and in vivo experimental models. Hence, the functional potency of our compounds was measured in isolated rat tissue while efficacy and liver safety were assessed in a rat model of hypertension and a model of hepatic bile salt transport interference, respectively. The corresponding efficacy and safety experiments certainly deliver composite readouts combining a multitude of parameters such as compound dissolution, absorption, potency on the target, binding kinetics, plasma protein binding, tissue distribution, metabolism, excretion, etc. While all these parameters can be studied individually, their importance and, in particular, their interplay is often difficult to assess. In this regard in vivo studies may offer a clear advantage as all these factors are incorporated in the study result. In our case, the ability to rapidly generate a large body of reliable and relevant in vivo data enabled us to establish SARs on in vivo efficacy and to monitor safety and only a limited number of experiments were needed to ensure that the data acquired in animals will positively translate to humans. Interestingly, a holistic approach emphasizing on in vivo data and an approach relying more on dissecting mechanistic studies may not necessarily lead to the same conclusions and decisions. This is illustrated with the result of the in vivo bile salt experiment. As outlined above, macitentan did not affect plasma bile salt levels upon i.v. injection in Wistar rats a result that significantly contributed to its selection for further development. At this point the question whether we would have selected macitentan if we had based our selection process on the in vitro BSEP inhibition data collected later remains an open one.

\section{Acknowledgements}

I would like to express my sincerest gratitude to my colleagues Christoph Boss, Sylvia Richard, Judith Marfurth, Udo Diessenbacher, David Monnard, Pascal Rebmann, Heiner

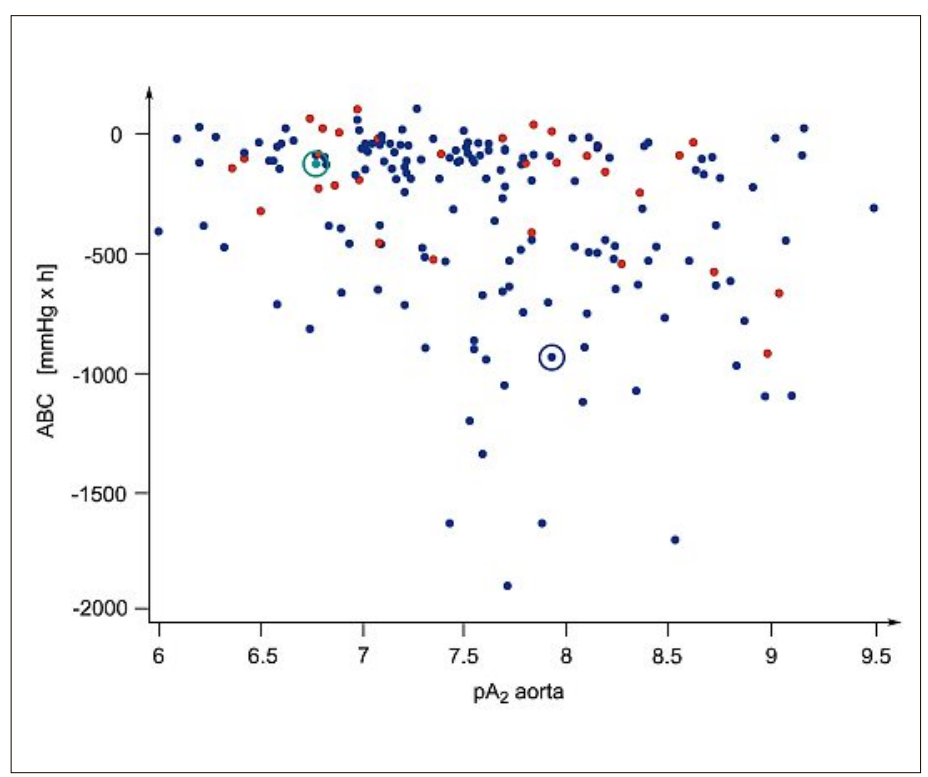

Fig. 12. ABC as calculated between the mean arterial blood pressure curves recorded before (control) and after administration of $3 \mathrm{mg} / \mathrm{kg}$ of pyrimidine (blue) or $30 \mathrm{mg} / \mathrm{kg}$ of benzodiazepinone (red) derivatives to hypertensive Dahl salt-sensitive rats versus $\mathrm{pA}_{2}$ values obtained from the isolated rat aorta constriction experiment; bosentan (3 mg/ $\mathrm{kg}$, light blue circle, $\mathrm{ABC}=-88 \mathrm{mmHg} \times$ h), macitentan (blue circle, $\mathrm{ABC}=-922$ $\mathrm{mmHg} \times \mathrm{h}$ ).

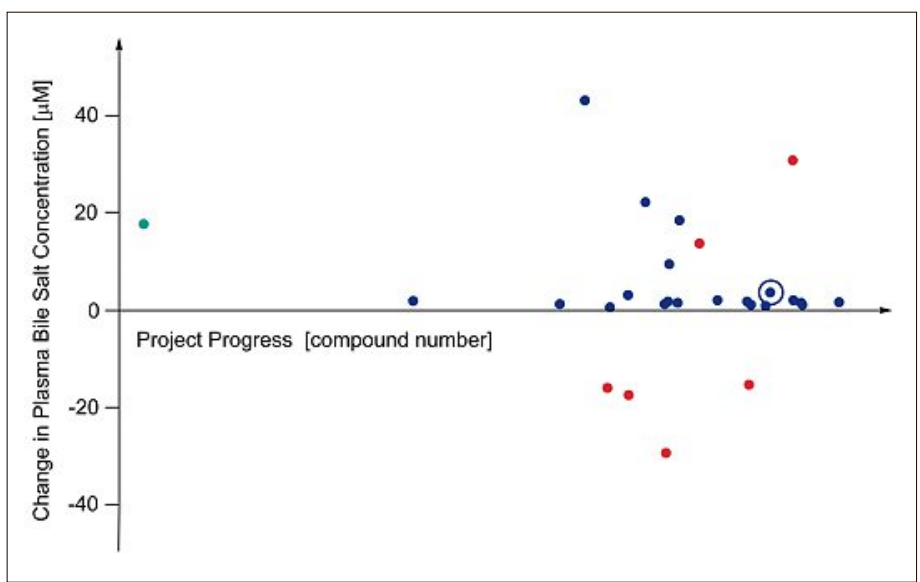

Fig. 13. Changes in plasma bile salt levels as measured $10 \mathrm{~min}$ after i.v. administration of $25 \mathrm{mg} / \mathrm{kg}$ of the compound to Wistar rats; pyrimidine series (blue), macitentan (in blue circle), bosentan (light blue), benzodiazepinones (red).

Table 3. In vivo SAR of the 5-substituent attached to the core pyrimidine. ${ }^{[52]}$<smiles>[R]c1c(NS(=O)(=O)NCc2ccccc2)ncnc1OCCOc1ncc(Br)cn1</smiles>

\begin{tabular}{|c|c|c|c|c|c|c|}
\hline \multirow{2}{*}{ Compound } & \multirow{2}{*}{$\mathrm{R}$} & \multicolumn{2}{|c|}{$\mathrm{IC}_{50}[\mathrm{nM}]$} & \multicolumn{2}{|c|}{$\mathrm{pA}_{2}$} & \multirow{2}{*}{$\begin{array}{c}\mathrm{ABC}^{\mathrm{a}} \\
{[\mathrm{mmHg} \times \mathrm{h}}\end{array}$} \\
\hline & & $\mathrm{ET}_{\mathrm{A}}$ & $\mathrm{ET}_{\mathrm{B}}$ & aorta & trachea & \\
\hline 30 & 2-methoxyphenoxy & 6.9 & 530 & n.d. & n.d. & -100 \\
\hline 31 & 3-methoxyphenoxy & 1.0 & 460 & n.d. & n.d. & -245 \\
\hline 32 & $\begin{array}{l}\text { 3-methoxy- } \\
\text { 6-chloro-phenoxy }\end{array}$ & 1.4 & 710 & 7.69 & 5.84 & -639 \\
\hline 33 & 4-chlorophenyl & 1.4 & 510 & 8.80 & 5.63 & -593 \\
\hline 34 & 4-bromophenyl & 1.6 & 460 & 8.44 & n.d. & -445 \\
\hline
\end{tabular}

aat $3 \mathrm{mg} / \mathrm{kg}$ p.o.

Bammerlin, Walter Schmutz, Gaby Vorburger, Adrian Hugi, Patrick Hess, Markus Rey, Daniel Wanner, Hélène Hettrich, Chris Binkert, Céline Mangold, Josiane Rein, John Gatfield, Célia
Müller, Katalin Menyhart, Marc Iglarz, Pauline Steiner, Alexander Treiber, Stéphane Delahaye, and Aude Weigel for their tireless efforts, their team spirit, enthusiasm, and commitment to the 
Table 4. In vivo SAR of the 5-substituent attached to the core pyrimidine.[52]

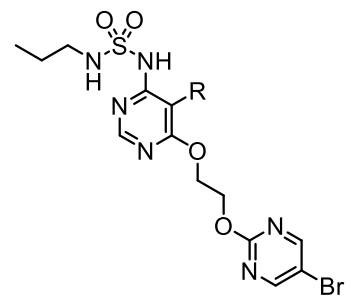

\begin{tabular}{|c|c|c|c|c|c|c|}
\hline \multirow{2}{*}{ Compound } & \multirow{2}{*}{$\mathrm{R}$} & \multicolumn{2}{|c|}{$\mathrm{IC}_{50}[\mathrm{nM}]$} & \multicolumn{2}{|c|}{$\mathrm{pA}_{2}$} & \multirow{2}{*}{$\begin{array}{c}\mathrm{ABC}^{\mathrm{a}} \\
{[\mathrm{mmHg} \times \mathrm{h}]}\end{array}$} \\
\hline & & $\mathrm{ET}_{\mathrm{A}}$ & $\mathrm{ET}_{\mathrm{B}}$ & aorta & trachea & \\
\hline 35 & 3-methoxyphenoxy & 1.9 & 468 & n.d. & n.d. & -391 \\
\hline 36 & $\begin{array}{c}\text { 6-chloro- } \\
\text { 3-methoxyphenoxy }\end{array}$ & 0.4 & 208 & 8.23 & 6.42 & -500 \\
\hline 1 & 4-bromophenyl & 0.5 & 391 & 7.93 & 6.82 & -922 \\
\hline
\end{tabular}

at $3 \mathrm{mg} / \mathrm{kg}$ p.o.

Table 5. In vivo SAR of the 5-substituent attached to the lower pyrimidine.[62]

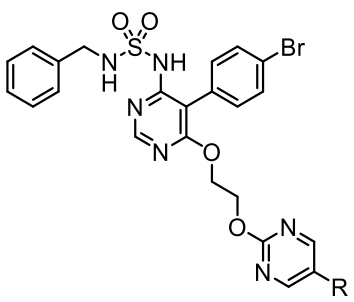

\begin{tabular}{ccccccc} 
& & \multicolumn{2}{c}{$\mathrm{IC}_{50}[\mathrm{nM}]$} & \multicolumn{2}{c}{$\mathrm{pA}_{2}$} & $\mathrm{ABC}^{\mathrm{a}}$ \\
Compound & $\mathrm{R}$ & $\mathrm{ET}_{\mathrm{A}}$ & $\mathrm{ET}_{\mathrm{B}}$ & aorta & trachea & {$[\mathrm{mmHg} \times \mathrm{h}]$} \\
$\mathbf{3 8}$ & cyclopropyl & 0.9 & 280 & 8.03 & n.d. & -23 \\
$\mathbf{3 9}$ & $\mathrm{OCH}_{3}$ & 1.7 & 260 & n.d. & n.d. & -85 \\
$\mathbf{3 4}$ & $\mathrm{SCH}_{3}$ & 0.4 & 60 & 8.40 & 6.76 & -506 \\
& $\mathrm{Br}$ & 1.6 & 460 & 8.44 & n.d. & -445
\end{tabular}

aat $3 \mathrm{mg} / \mathrm{kg}$ p.o.

project, and Thomas Weller, Walter Fischli, and Martine Clozel for their unlimited trust, support, and advice.

Received: June 1, 2017

[1] M. Clozel, W. Fischli, J. Cardiovascular Pharmacol. 1989, 13 Suppl 5, S229.

[2] W. Fischli, M. Clozel, C. Guilly, Life Sci. 1989 , 44, 1429.

[3] M. Clozel, W. Fischli, C. Guilly, J. Clin. Invest. 1989, 83, 1758.

[4] M. Clozel, J. P. Clozel, J. Pharmacol. Exp. Ther. 1989, 250, 1125 .

[5] M. Clozel, J. Hypertens. 1989, 7, 913

[6] M. Clozel, V. Breu, K. Burri, J.-M. Cassal, W. Fischli, G. A. Gray, G. Hirth, B.-M. Löffler, M. Müller, W. Neidhart, H. Ramuz, Nature 1993, 365,759 .

[7] M. Clozel, V. Breu, FEBS Lett. 1996, 383, 42.

[8] P. H. Dagassan, V. Breu, M. Clozel, A. Künzli, P. Vogt, M. Turina, W. Kiowski, J.-P. Clozel, J. Cardiovasc. Pharmacol. 1996, 27, 147.

[9] M. Clozel, H. Salloukh, Ann. Med. 2005, 37, 2.

[10] M. Clozel, S. Flores, Drug Dev. Res. 2006, 67, 825.
[11] W. Neidhart, V. Breu, D. Bur, K. Burri, M. Clozel, G. Hirth, M. Müller, H. P. Wessel, H. Ramuz, Chimia 1996, 50, 519.

[12] M. Clozel, V. Breu, G. A. Gray, B. Kalina, B. M. Löffler, K. Burri, J.-M. Cassal, G. Hirth, M. Müller, W. Neidhart, H. Ramuz, J. Pharm. Exper. Ther. 1994, 270, 228.

[13] W. Kiowski, G. Sutsch, P. Hunziker, P. Muller, J. Kim, E. Oechslin, R. Schmitt, R. Jones, O. Bertel, Lancet 1995, 346, 732.

[14] C. Weber, R. Schmitt, H. Birnboeck, G. Hopfgartner, S. P. van Marle, P. A. Peeters, J. H. Jonkman, C. R. Jones, Clin. Pharmacol. Ther. 1996, 60, 124

[15] H. Krum, V. Charlon, T. Widmann, M. Packer, Circulation 1999, 100, Abst 3408.

[16] M. Yanagisawa, H. Kurihara, S. Kimura, Y. Tomobe, M. Kobayashi, Y. Mitsui, K. Goto, T. Masaki, Nature 1988, 332, 411.

[17] M. L. Webb, T. D. Meek, Med. Res. Revs. 1997, 17, 17.

[18] M. Iglarz, M. Clozel, Clin. Sci. 2010, 119, 453

[19] A. Benigni, G. Remuzzi, Lancet 1999, 353, 133.

[20] G. Remuzzi, N. Perico, A. Benigni, Nature Rev. Drug Discov. 2002, 1, 986.

[21] J. Nelson, A. Bagnato, B. Battistini, P. Nisen, Nature Rev. Cancer 2003, 3, 110.

[22] C. Fonseca, D. Abraham, E. A. Renzoni, Am. J. Respir. Cell Mol. Biol. 2011, 44, 1.
[23] J. Dupuis, M. M. Hoeper, Eur. Respir. J. 2008, 31, 407.

[24] M. Kakoki, Y. Hirata, H. Hayakawa, A. Tojo, D. Nagata, E. Suzuki, K. Kimura, A. Goto, K Kikuchi, T. Nagano, M. Omata, Circulation 1999, 99, 1242

[25] M. Iglarz, P. Steiner, D. Wanner, M. Rey, P. Hess, M. Clozel, J. Cardiovasc. Pharmacol. 2015, 66, 332.

[26] P. Mulder, H. Boujedaini, V. Richard, G. Derumeaux, J. P. Henry, S. Renet, J. Wessale, T. Opgenorth, C. Thuillez, Circulation 2000, 102, 491.

[27] J. F. Jasmin, M. Lucas, P. Cernacek, J. Dupuis, Circulation 2001, 103, 314.

[28] L. L. Yang, R. Gros, M. G. Kabir, A. Sadi, A. I. Gotlieb, M. Husain, D. J. Stewart, Circulation 2004, 109, 255.

[29] B. Hocher, P. Kalk, T. Slowinski, M. Godes, A. Mach, S. Herzfeld, D. Wiesner, P. C. Arck, H. H. Neumayer, B. Nafz, J. Am. Soc. Nephrol. 2003, 14,367 .

[30] M. Vercauteren, F. Trensz, A. Pasquali, C Cattaneo, D. S. Strasser, P. Hess, M. Iglarz, M. Clozel, J. Pharmacol. Exp. Ther. 2017, 361, 322.

[31] K. Sato, M. Oka, K. Hasunuma, M. Ohnishi, S. Kira, Am. J. Physiol. 1995, 269, L668.

[32] T. Fukuroda, S. Ozaki, M. Ihara, K. Ishikawa, M. Yano, T. Miyauchi, S. Ishikawa, M. Onizuka, K. Goto, M. Nishikibe, Br. J. Pharmacol. 1996, 117, 995.

[33] T. E. King, Jr., K. K. Brown, G. Raghu, R. M du Bois, D. A. Lynch, F. Martinez, D. Valeyre, I. Leconte, A. Morganti, S. Roux, J. Behr, Am. J. Respir. Crit. Care Med. 2011, 184, 92.

[34] G. Raghu, J. Behr, K. K. Brown, J. J. Egan, S. M. Kawut, K. R. Flaherty, F. J. Martinez, S. D. Nathan, A. U. Wells, H. R. Collard, U. Costabel, L. Richeldi, J. de Andrade, N. Khalil, L. D. Morrison, D. J. Lederer, L. Shao, X. Li, P. S. Pedersen, A. B. Montgomery, J. W. Chien, T. G. O'Riordan, Ann. Intern. Med. 2013, 158, 641.

[35] V. Breu, S. I. Ertel, S. Roux, M. Clozel, Exp. Opin. Invest. Drugs 1998, 7, 1173.

[36] J. R. Teerlink, B. M. Loffler, P. Hess, J. P. Maire, M. Clozel, J. P. Clozel, Circulation 1994, 90 2510.

[37] P. Mulder, V. Richard, G. Derumeaux, M. Hogie, J. P. Henry, F. Lallemand, P. Compagnon, B. Mace, E. Comoy, B. Letac, C. Thuillez, Circulation 1997, 96, 1976.

[38] S. Eddahibi, B. Raffestin, M. Clozel, M. Levame, S. Adnot, Am. J. Physiol. 1995, 268, H828.

[39] P. Holm, J. Liska, M. Clozel, A. FrancoCereceda, J. Thorac. Cardiovasc. Surg. 1996, $112,890$.

[40] P. Hess, M. Clozel, J.-P. Clozel, J. Appl. Physiol. 1996, $81,1027$.

[41] G. Sutsch, O. Bertel, W. Kiowski, Cardiovasc Drugs Ther. 1997, 10, 717.

[42] H. Krum, Circulation 1997, 96 (8, Suppl.), Abst 2279.

[43] R. N. Channick, L. Rubin, G. Simmoneau, I. Robbins, V. Tapson, D. B. Badesch, F. Bodin, Circulation 2000, 102 (18, Suppl.), Abst 476.

[44] R. N. Channick, G. Simonneau, O. Sitbon, I. M. Robbins, A. Frost, V. F. Tapson, D. B. Badesch, S. Roux, M. Rainisio, F. Bodin, L. J. Rubin, Lancet 2001, 358, 1119.

[45] L. J. Rubin, S. Roux, Exp. Opin. Invest. Drugs 2002, 11, 991 .

[46] U.S. Food and Drug Administration, Tracleer (bosentan), https://www.accessdata.fda.gov/ drugsatfda_docs/label/2009/021290s012lbl.pdf accessed: April 2017

[47] J. Dingemanse, P. L. van Giersbergen, Clin. Pharmacokinet. 2004, 43, 1089.

[48] S. Dhillon, G. M. Keating, Am. J. Cardiovasc. Drugs 2009, 9, 331

[49] K. Fattinger, C. Funk, M. Pantze, C. Weber, J. Reichen, B. Stieger, P. J. Meier, Clin. Pharmacol. Ther. 2001, 69, 223. 
[50] B.-M. Löffler, V. Breu, M. Clozel, FEBS Lett. 1993, 333, 108.

[51] J. Dupuis, C. A. Goresky, A. Fournier, J. Appl. Physiol. 1996, 81, 1510.

[52] M. H. Bolli, C. Boss, C. Binkert, S. Buchmann, D. Bur, P. Hess, M. Iglarz, S. Meyer, J. Rein, M. Rey, A. Treiber, M. Clozel, W. Fischli, T. Weller, J. Med. Chem. 2012, 55, 7849.

[53] A. Treiber, P. Aanismaa, R. de Kanter, S. Delahaye, M. Treher, P. Hess, P. Sidharta, $J$. Pharmacol. Exp. Ther. 2014, 350, 130.

[54] M. Iglarz, C. Binkert, K. Morrison, W. Fischli, J. Gatfield, A. Treiber, T. Weller, M. H. Bolli, C. Boss, S. Buchmann, B. Capeleto, P. Hess, C. Qiu, M. Clozel, J. Pharm. Exp. Ther. 2008, 327, 736.

[55] M. Rey, E. W. Weber, P. D. Hess, J. Am. Assoc. Lab. Anim. Sci. 2012, 51, 231.

[56] W. Neidhart, J. Ackermann, K. Amrein, A. Conte, D. Hunziker, B. Kuhn, H. P. Märki, M. Nettekoven, A. Ruf, T. Schulze-Gasch, A. V. Mayweg, Chimia 2016, 69, 407.

[57] B. Jarvis, R. Duff, S. Elkinson, Drugs R D 1999, $2,13$.

[58] J. R. Wu-Wong, R. Padley, Curr. Opin. Cardiovasc. Pulmon. \& Renal Invest. Drugs 2000, 2, 339.

[59] W. M. Clark, Curr. Opin. Drug Discov. Dev. $1999,2,565$.

[60] C. Boss, M. Bolli, T. Weller, Curr. Med. Chem. 2002, 9, 349.

[61] F. Dasgupta, A. K. Mukherjee, N. Gangadhar, Curr. Med. Chem. 2002, 9, 549.

[62] 'The Discovery of Macitentan - A Standard Medicinal Chemistry Program' M. H. Bolli, C. Boss, J. Gatfield, M. Iglarz, A. Treiber, in 'Comprehensive Medicinal Chemistry III', Eds D. Rotella, S. Chackalamannil, S. Ward, Elsevier: Oxford, 2016; Vol. 8, in press.

[63] J. Sakaki, T. Murata, Y. Yuumoto, I. Nakamura, K. Hayakawa, Bioorg. Med. Chem. Lett. 1998, $8,2247$.

[64] J. Zhang, S. Didierlaurent, M. Fortin, D. Lefrancois, E. Uridat, J. P. Vevert, Bioorg. Med. Chem. Lett. 2000, 10, 1351.

[65] D. L. Williams, Jr., K. L. Murphy, N. A. Nolan, J. A. O'Brien, D. J. Pettibone, S. D. Kivlighn, S. M. Krause, E. V. Lis, Jr., G. J. Zingaro, R A. Gabel, et al., J. Pharmacol. Exp. Ther. 1995, 275,1518 .

[66] H. Riechers, H.-P. Albrecht, W. Amberg, E. Baumann, H. Bernard, H.-P. Böhm, D. Klinge, A. Kling, S. Müller, M. Raschak, L. Unger, N Walker, W. Wernet, J. Med. Chem. 1996, 39 , 2123

[67] C. Boss, M. H. Bolli, J. Gatfield, Bioorg. Med. Chem. Lett. 2016, 26, 3381.

[68] J. Gatfield, C. Mueller Grandjean, T. Sasse, M. Clozel, O. Nayler, PLoS One 2012, 7, e47662.

[69] M. H. Bolli, J. Marfurt, C. Grisostomi, C. Boss, C. Binkert, P. Hess, A. Treiber, E. Thorin, K. Morrison, S. Buchmann, D. Bur, H. Ramuz, M. Clozel, W. Fischli, T. Weller, J. Med. Chem. 2004, 47, 2776.

[70] J. Gatfield, C. Mueller Grandjean, D. Bur, M. H. Bolli, O. Nayler, PLoS One 2014, 9 , e107809.

[71] M. Iglarz, K. Landskroner, Y. Bauer, M Vercauteren, M. Rey, B. Renault, R. Studer, E. Vezzali, D. Freti, H. Hadana, M. Schlapfer, C. Cattaneo, C. Bortolamiol, E. Weber, B. R Whitby, S. Delahaye, D. Wanner, P. Steiner, O. Nayler, P. Hess, M. Clozel, J. Cardiovasc. Pharmacol. 2015, 66, 457.

[72] M. Iglarz, A. Bossu, D. Wanner, C. Bortolamiol, M. Rey, P. Hess, M. Clozel, Life Sci. 2014, 118 , 333.

[73] T. Pulido, I. Adzerikho, R. N. Channick, M. Delcroix, N. Galie, H. A. Ghofrani, P. Jansa, Z. C. Jing, F. O. Le Brun, S. Mehta, C. M. Mittelholzer, L. Perchenet, B. K. Sastry, O. Sitbon, R. Souza, A. Torbicki, X. Zeng, L. J. Rubin, G. Simonneau, N. Engl. J. Med. 2013, 369, 809.<smiles>CCCNS(=O)(=O)Nc1ncnc(OCCOc2ncc(Br)cn2)c1-c1ccc(Br)cc1</smiles>

B

$$
\begin{array}{cccc}
\multicolumn{5}{c}{\text { macitentan } 1} \\
\mathrm{IC}_{50} \mathrm{ET}_{\mathrm{A}} & 0.5 \mathrm{nM} & \mathrm{pA}_{2} \text { aorta } & 7.93 \\
\mathrm{ET}_{\mathrm{B}} & 391 \mathrm{nM} & \text { trachea } & 6.82
\end{array}
$$

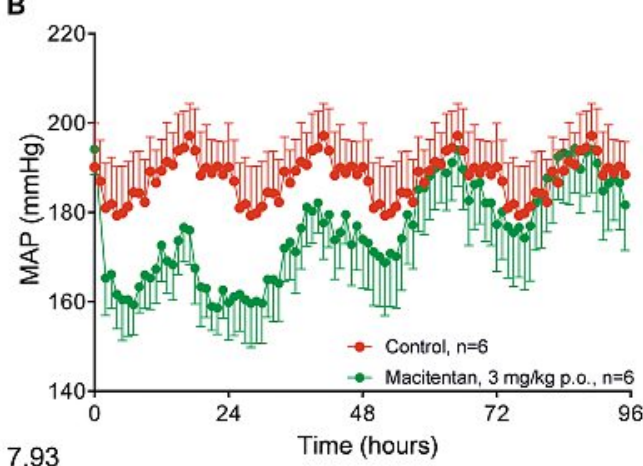

Dahl S ABC $-922 \mathrm{mmHg} \times \mathrm{h}$

no cholestatic effect in rats

Fig. 14. A) Structure, in vitro and in vivo data of macitentan (1). B) MAP recordings $96 \mathrm{~h}$ before (control) and after administration of $3 \mathrm{mg} / \mathrm{kg}$ of macitentan to hypertensive Dahl salt-sensitive rats. $A B C=$ area between the curve before and after compound administration.

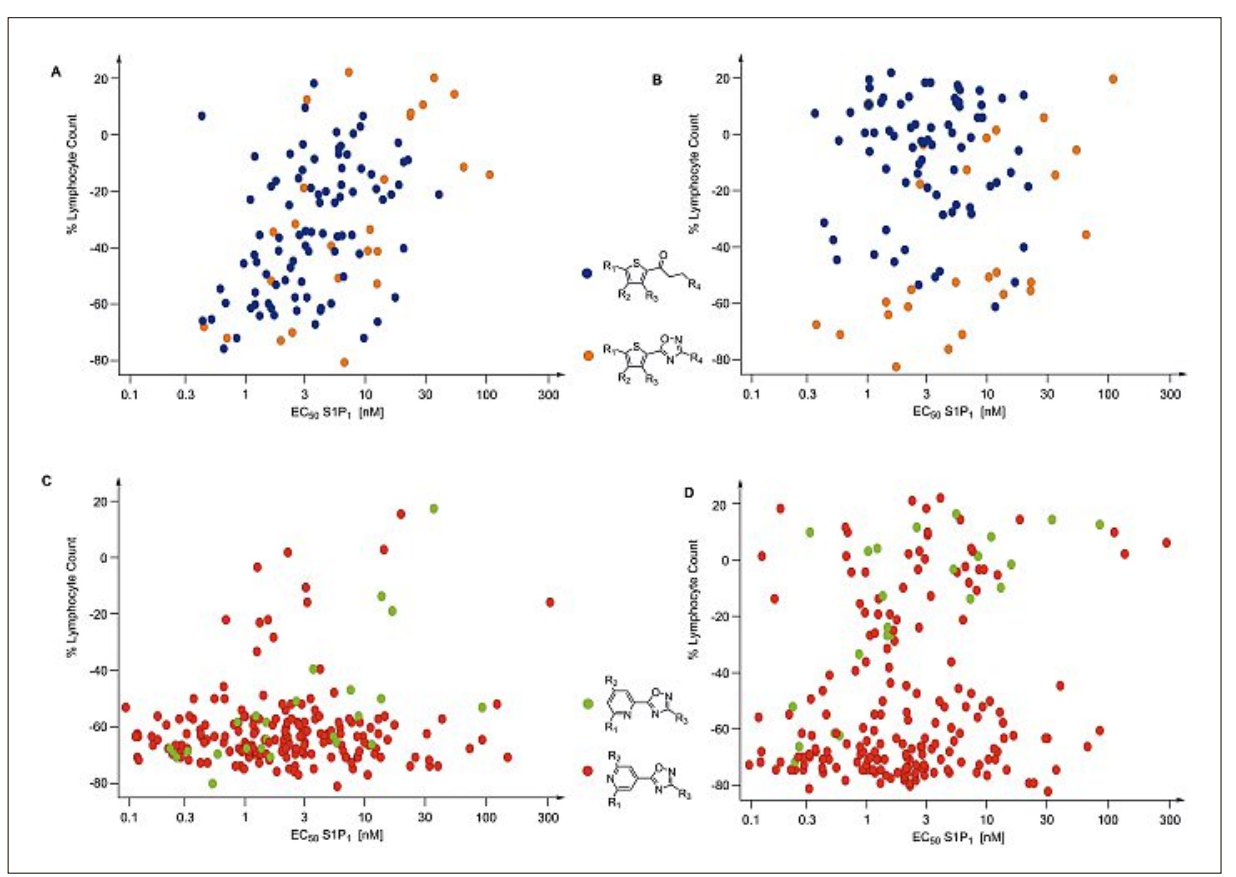

Fig. 15. Plotting S1P $\mathrm{P}_{1} \mathrm{GTP} \gamma \mathrm{S} \mathrm{EC}_{50}[\mathrm{nM}]$ values against blood $\mathrm{LC}$ reduction [\% of baseline] in Wistar rats $3 \mathrm{~h}(\mathrm{~A}, \mathrm{C})$ and $24 \mathrm{~h}(\mathrm{~B}, \mathrm{D})$ after receiving $10 \mathrm{mg} / \mathrm{kg}$ p.o.; dark blue = thiophene ketones, orange $=$ thiophene oxadiazoles, light green $=2$-pyridyl-oxadiazoles, red $=4$-pyridyl-oxadiazoles .

[74] S. Mandala, R. Hajdu, J. Bergstrom, E. Quackenbush, J. Xie, J. Milligan, R. Thornton, G.-J. Shei, D. Card, C. A. Keohane, M. Rosenbach, J. Hale, C. L. Lynch, K. Rupprecht, W. Parsons, H. Rosen, Science 2002, 296, 346.

[75] M. Matloubian, C. G. Lo, G. Cinamon, M. J. Lesneski, Y. Xu, V. Brinkmann, M. L. Allende, R. L. Proia, J. G. Cyster, Nature 2004, 427, 355.

[76] H. Rosen, E. J. Goetzl, Nature Rev. Immunol. 2005, 5,560 .

[77] M. H. Bolli, C. Müller, B. Mathys, S. Abele, M. Birker, R. Bravo, D. Bur, P. Hess, C. Kohl, D. Lehmann, O. Nayler, M. Rey, S. Meyer, M. Scherz, G. Schmidt, B. Steiner, A. Treiber, J. Velker, T. Weller, J. Med. Chem. 2013, 56, 9737.

[78] M. H. Bolli, J. Velker, C. Müller, B. Mathys, M. Birker, R. Bravo, D. Bur, R. de Kanter, P. Hess, C. Kohl, D. Lehmann, S. Meyer, O. Nayler, M. Rey, M. Scherz, B. Steiner, J. Med. Chem. 2014, 57, 78.
[79] M. H. Bolli, S. Abele, M. Birker, R. Bravo, D. Bur, R. de Kanter, C. Kohl, J. Grimont, P. Hess, C. Lescop, B. Mathys, C. Muller, O. Nayler, M. Rey, M. Scherz, G. Schmidt, J. Seifert, B. Steiner, J. Velker, T. Weller, J. Med. Chem. 2014, 57, 110 .

[80] C. Lescop, C. Müller, B. Mathys, M. Birker, R de Kanter, C. Kohl, P. Hess, O. Nayler, M. Rey, B. Steiner, J. Velker, T. Weller, M. H. Bolli, Eur. J. Med. Chem. 2016, 115, 222.

[81] M. H. Bolli, C. Lescop, M. Birker, R. de Kanter, P. Hess, C. Kohl, O. Nayler, M. Rey, P. Sieber, J. Velker, T. Weller, B. Steiner, Eur. J. Med. Chem. 2016, 115, 326.

[82] M. H. Bolli, C. Boss, M. Clozel, W. Fischli, T. Weller, 'Novel Alkansulfonamides as Endothelin Receptor Antagonists', WO2003055863, July 10, 2003. 